\title{
Role of Green Jobs in the Reduction of Waste and Waste Management
}

\author{
Rudite VESERE ${ }^{1 *}$, Silvija Nora KALNINS², Dagnija BLUMBERGA ${ }^{3}$ \\ ${ }^{1-3}$ Institute of Energy Systems and Environment, Riga Technical University, Āzenes iela 12/1, Riga, \\ LV-1048, Latvia
}

\begin{abstract}
The paper examines the role and place of green enterprises, green jobs and the environmentally sound activities of society in waste management, taking into account the waste management hierarchy with an emphasis on waste reduction and prevention. In the course of the work, a questionnaire was prepared on the role green enterprises, green jobs and the environmentally friendly activities of society play in the development of a waste management system. The TOPSIS method of multi-criteria analysis was used to assess these roles in the development of a circular economy, including in relation to a waste management system. Through the assessment of the roles of these green measures in the field of waste management, the results clearly show that the most effective of the selected alternatives in the circular economy model in the field of separate collection and recycling of waste can be achieved via measure exercised by green enterprises, followed by green jobs and finally - the role of environmentally sound activities taken by the public, which play an important role as well.
\end{abstract}

Keywords - Green enterprises; green jobs; TOPSIS; waste management; waste reduction

\section{INTRODUCTION}

Sustainable development includes economic growth, social progress and respect for the environment. This is an important aspect of the circular economy to address in the transition from waste to resource management and in the promotion of sustainable consumption. This paper assesses one aspect of sustainable development and the circular economy - the social dimension and progress based on the experience and research of different countries, focusing on green entrepreneurship, green jobs, their motivating aspects and approaches, and societal initiatives that promote them.

Between the years 2012 and 2018, the number of jobs in the circular economy within the European Union increased by $5 \%$ to around 4 million. The circular economy can be expected to have a positive effect on job creation, provided that workers acquire the skills required by the green economy transition. The mutual benefits of supporting the green transition and strengthening social inclusion help to further unlock the potential for job creation in the circular economy [1].

As the scarcity of raw materials becomes more pronounced, green growth is of paramount importance, as the traditional consumer-driven society, where unnecessary things are thrown away, is not sustainable. The recycling of raw materials not only leads to a longer use of products in the economy, but also contributes to the creation of new industries and jobs, thus having a positive impact on the economy as a whole.

* Corresponding author.

E-mail address: ruditevesere@yahoo.com 
In order to assess what preconditions are needed and what motivates the growth and development of green jobs, this paper analyses the available information and conducts a survey of experts and students working in the circular economy and waste management who are not directly involved in green jobs. The paper evaluates several aspects of green jobs green enterprises and the jobs available in these enterprises, and green jobs in other enterprises and institutions, as well as environmentally friendly activities engage in by the public and the opportunities to develop them further in context with the transition to a circular economy.

\section{GREEN ENTERPRISES AND GREEN JOBS AND THEIR ROLE IN THE Circular ECONOMY}

As defined by the International Labour Organization (ILO), green jobs (GJSs) [2] are jobs that facilitate a sustainable conservation or renewal of environmental quality in the agricultural, industrial, construction, service sectors or administration. Green jobs are 'decent jobs that contribute to preserve or restore the environment, be they in traditional sectors such as manufacturing and construction, or in new, emerging green sectors such as renewable energy and energy efficiency'. It is widely acknowledged that successful transition to a green, resource- and energy-efficient economy will transform labour markets [1]-[7].

GJSs reduce the environmental impact of individual companies and the economic sector as a whole and help to achieve sustainability, to reduce the consumption of energy, raw materials and water, to promote a low-carbon economy and reduce greenhouse gas emissions. GJs are not just jobs in new industries or green businesses, but include all jobs created in all sectors, which reduce the environmental impact of production processes and products. GJs also include employees who work in accordance with and promote compliance with environmentally friendly standards [2].

Green jobs help to improve efficiency in energy and raw material use, limit greenhouse gas emissions, reduce volumes of waste created and volumes brought to landfill, reduce environmental emissions and protect and restore ecosystems. At the company level, green jobs can be created by producing goods or providing services that benefit the environment, such as constructing eco-efficient buildings, using low-emission transport, producing goods and energy from secondary raw materials [7]-[10].

Green jobs can be distinguished by their contribution to more environmentally friendly processes. For example, they can reduce water consumption, waste generation or improve waste recycling technologies. GJs also include consultants who help companies to implement environmental policy more effectively.

As illustrated [11], it is possible to distinguish employment in sectors of the green economy from the point of view of production and job functions in all sectors, and from the point of view of the green processes. The International Labour Organization considers that green jobs are all jobs that fall within the overlapping areas of Fig. 1.

In order to facilitate the transition to a green and resource-efficient economy, dynamic and well-functioning labour markets need to focus on addressing skills shortages, anticipating change, ensuring transition and facilitating mobility. In this way, it is possible to support the creation of green jobs. Various criteria can be used to determine whether a workplace is a green job [2], [11]:

- Corresponding commercial certificate;

- Industry-standard classification systems, such as the NACE (Nomenclature of Economic Activities) code in the European Union (determination of whether the 
enterprise is a green enterprise);

- Eco-labelling of the product/good used in production;

- Descriptions of the technology used, production patents/licenses;

- Contracts with waste management and recycling companies such as contracts for the management of all waste created.

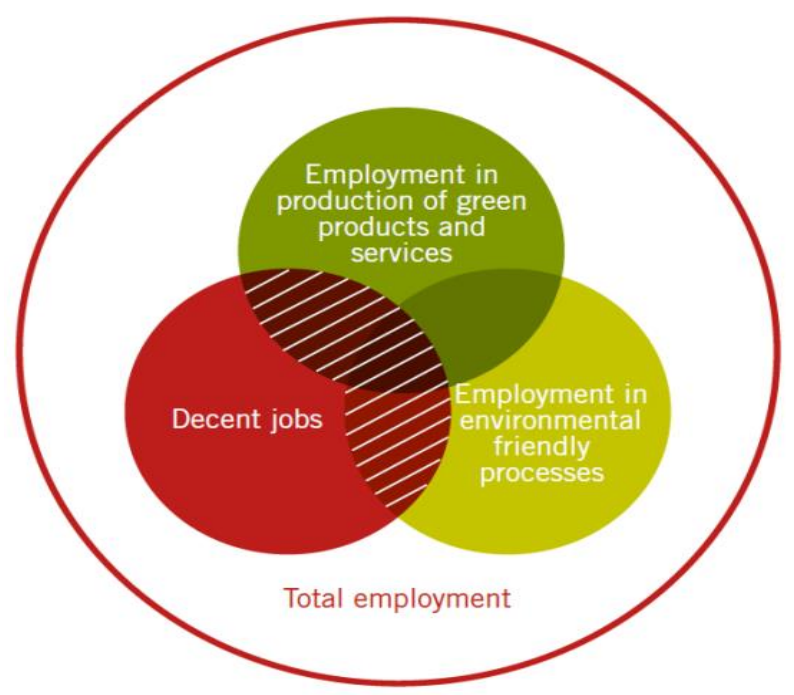

Fig. 1. Employment in environmentally friendly economic sectors in terms of production and job functions in all sectors from the perspective of green processes [11].

Following the green economy paradigm, research on environmentally friendly jobs focuses on the link between the growth of the circular economy and impact on the creation of new green jobs. The European Union estimates that while the green economy will create new jobs and open new markets, Europe's competitiveness, innovation and productivity will be highly dependent on the availability of skilled workers [1]. This means there needs to be an assessment of how skills development and the need for skills across sectors can be better forecasted to enable relevant authorities and stakeholders to adapt to change. Skills related to the circular economy are not always completely new or 'unique'. They combine transversal competences and 'specific' skill sets. In some cases, tasks and responsibilities that require a specific combination of skills and knowledge create new occupational profiles. Promoting the adaptation of the workforce and education and training systems requires targeted action by public authorities to support transition to an effective response from education and training systems in providing the new skills and qualifications required. This calls for a review and update of qualifications and relevant education and training programs.

The interconnected issues of the circular economy, green jobs and the environmental goods and services sector have been addressed in the work [12]. The paper assesses the most common approaches to the circular economy based on the concept of sustainable development and provides an analysis of how green jobs can be used to tackle youth unemployment in Poland, the Czech Republic and Belgium. It was found that in both Poland and Belgium, around $15 \%$ of young people find their first job in a green job, while in the Czech Republic the proportion is much lower at only $1.83 \%$. The paper concludes that the growing emphasis on building a circular economy provides employment opportunities for young people seeking 
work for the first time. This means that green jobs can, in some countries, also be a solution to problems youths face in the labour market.

Another study [13] aimed to link new GJs and new environmentally friendly green business models to industrial transformation, drawing on the experience of two Italian industrial areas where environmental agreements have been implemented. Stakeholder cooperation as well as industry-research interactions were the main drivers in this scenario. In contrast, bureaucracy and lack of infrastructure investment are cited as obstacles to the creation of green jobs and the development of local green businesses. In order to identify the enabling conditions and define the barriers and the implementation of the applicable policy development programs and their activities, it is necessary to compare regions with similar conditions. Research into the use of renewable energy sources (RES) in the energy sector [14] has shown that they bring significant employment benefits. In order to evaluate professions in the RES sector, the use of investment-output analysis is proposed. Increasing employment is one of the most important benefits, especially in times of a crisis economy, including the use of specially prepared waste as energy.

Green jobs are a key societal goal to specifically support long-term efforts to reconcile sustainability and development. An econometric analysis of European small and mediumsized enterprises (SMEs) has been carried out to assess the factors influencing the creation of green jobs in SMEs [15]. It should be noted that innovation in environmentally friendly products and services is mainly related to the creation of green jobs [15], [16]. According to a study of data on the United States of America [17], green jobs make more intensive use of high-level cognitive and interpersonal skills than non-green jobs. It is also important to understand whether and how employees' attitudes towards green jobs are affected by environmental standards [18]-[23]. It is concluded that they motivate GJs quite indirectly. The implementation of environmental standards can also be facilitated by motivating employees in the social field. Therefore, it has been studied whether employees working in companies that register in the register of environmental standards show a positive attitude towards their work, are actively involved in their work and show an active result. Using the French harmonized database of employers and employees, it has been concluded [23] that these 'green workers' show significantly higher efficiency and recognition at work. Further research is now needed on the development of green skills, competencies and green jobs in companies in response to market and policy levers.

\section{Methodology}

This work focuses on green businesses and GJs in relation to waste management, following the waste hierarchy and focusing on waste reduction and prevention, waste recycling and energy production from waste, where the most efficient results can be achieved by implementing separate waste collection. In addition, the development and production aspects of any product, i.e. eco-design aspects, should be assessed, as they are closely linked to the generation and management of waste, but require separate assessment.

During the research, a questionnaire was developed on the role and place of green enterprises, green jobs and green activities engaged in by society in the development of the waste management system, especially in the promotion of waste reduction and prevention and in developing separate waste collection.

In this case, GJs were assumed to be jobs that contribute to the preservation or restoration of the environment, whether in traditional sectors such as manufacturing and construction, or in new, emerging green sectors such as renewable energy, or in traditional green companies such as waste management companies, etc. It was assumed that the successful transition to a 
green, resource- and energy-efficient economy transforms the labour market and that green jobs can be found both in green companies and in companies that are not considered green. Green jobs are distinguished by their contribution to environmentally friendly processes. Green jobs can be found both in green enterprises and in others that may not be considered green companies. For example, environmentally friendly workplaces can reduce the consumption of goods, reduce the amount of packaging used, facilitate the transition from consumption of goods to providing services, reduce the amount of waste generated, reduce the amount of waste disposed of and improve recycling technologies. At the same time, it was considered that GJ production processes do not always produce environmental goods or services.

Moreover, green entrepreneurship in the context of this paper is an activity that consciously addresses environmental and social issues and needs, as well as offers excellent innovative business ideas. The goals of green business are not only to generate financial profits, but also to ensure sustainable development, reduce environmental risks and pay more attention to environmental issues. Green business creates added value without compromising the quality of nature and the quality and volume of ecosystem services.

In the context of the public green activity survey, there are initiatives and activities of individual public interest groups, involving the public and various experts, with the aim of promoting a common understanding of sustainable living, eco-smart farming, biodiversity, empathy for the environment and useful solutions to change everyday habits. These activities involve environmental activism and the involvement of civil society in addressing environmental issues, working with other associations, initiative groups and individuals at local and national level, providing advice and other support. The aim of the activities is to promote the integration of environmental policy into sectoral policies and to promote environmental education through the dissemination of information and the organization of public events. In Latvia, examples of such environmental education and information activities are: Lielā talka (nation-wide clean-up campaign), Dabas koncertzāle (a multi-media awareness raising event on nature protection issues), zero waste initiatives and activities conducted by various non-governmental organizations such as 'Zạ̣ā brīvība' .

For the purposes of this work, green entrepreneurs are waste management companies that collect, sort and/or prepare waste for recycling and recovery, perform waste recycling or recovery, repair, repair and/or prepare for re-use. These companies ensure proper waste management by reducing the amount of waste disposed of in landfills and increasing waste recycling. In addition, companies that conduct repairs and repair items, extend the life of those items and thus, prevent waste. As a result of green business, the preservation of environmental quality and increased resource efficiency is ensured, which is one of the cornerstones of the circular economy. Green jobs, on the other hand, can be found in different companies and organizations, all of which generate waste, and such GJ can both ensure that the waste generated is properly managed and reduce the amount of waste generated. Society's green activities also promote and ensure that the waste generated is properly managed, and the amount of waste generated is also reduced. Respectively, all these groups have one goal and all of these groups can achieve the goal of preventing waste, reducing the amount of waste going to landfill and increasing the amount of waste recycled, thus increasing resource efficiency. The aim of the research was to find out which of the above groups contribute the most to the achievement of the goals of the circular economy - the reduction of waste and efficient management.

More than 20 Latvian environmental experts were involved in the survey, including specialists in the field of waste management. The transition to a circular economy has a significant impact on skills needs, with a growing demand for skilled labour in environmental 
sectors, raising the skills of employees in all sectors and re-training employees in sectors undergoing restructuring, thus 19 Latvian students studying finance and accounting and 6 students studying business management in Latvia were also included in the survey. The study programs of the mentioned study courses also include the basics of environmental protection and waste management.

Those surveyed were asked to assess green businesses, GJs and the green activities engaged in by the public, identifying which group has the most important influence in terms of the following aspects - education, innovative thinking, economic aspects, social benefits, environmental and climate aspects and motivation to achieve circular economy goals.

The criterion on the need for education referred to the need for specific level of education or specific skills to perform activities in the workplace or to be involved in public activities. The innovation aspect related to the level and necessity of technology, methods used, operational novelty, as well as their efficiency. Economic aspects include tax policy, costs, the added value of the product or service provided. Social benefits are related to the image, prestige, quality of performance and public evaluation of the company, workplace, part of the society (association, organization). Environmental aspects are the direct and indirect impact of the activity on the environment, measures and opportunities for pollution reduction and prevention, changes in the state of environmental quality. Climate aspects are directly linked to the potential for mitigating the effects of action on climate change. Achieving the goals of the activity requires motivation, on which the efficiency of the activity, benefits, impact on competition depend as an internal factor.

The participants in the survey were asked to assess the impact of these seven aspects in green enterprises, green jobs and green activities engaged in by the public on a scale from zero to five, zero meaning 'no opinion' and 5 meaning the aspect is very important.

The results of the survey were compared considering the valuation submitted by the experts and students. The results were tabulated with the expert opinion results and those of the students provided separately, as well as combined (Table 1).

TABLE 1. COMBINED VALUATION FROM THE EXPERTS AND STUDENTS OF THE ROLE IN THE CIRCULAR ECONOMY OF GREEN ENTERPRISES, GREEN JOBS AND ENVIRONMENTALLY FRIENDLY ACTIVITIES IN ENGAGED IN BY THE PUBLIC

\begin{tabular}{llll}
\hline Valuation aspects & $\begin{array}{l}\text { Green } \\
\text { enterprises }\end{array}$ & Green jobs & $\begin{array}{l}\text { Environmentally } \\
\text { friendly activities } \\
\text { engaged in by the } \\
\text { public }\end{array}$ \\
\hline $\begin{array}{l}\text { Necessity for } \\
\text { education }\end{array}$ & 4.07 & 3.66 & 3.44 \\
Innovation & 4.43 & 3.75 & 3.04 \\
Economic & 4.50 & 3.60 & 2.80 \\
Social benefits & 4.46 & 3.91 & 3.87 \\
Environmental & 4.67 & 4.29 & 4.44 \\
Climate-related & 4.47 & 3.98 & 4.15 \\
Motivation & 4.40 & 3.91 & 3.94 \\
\hline
\end{tabular}


As can be seen from the results of the expert survey, the most important aspects in the performance of green companies are considered to be innovation and environmental protection, while the need for special education is rated the lowest. Innovative thinking, economic aspects and motivation should be mentioned as the most important aspects of GJ performance, but social benefits are the least important. Environmental and climate aspects are the most important for the activities engaged in by the public, but economic aspects are the least important for this category of activity.

In accordance with the valuation on part of the students, the most important aspects in the performance of green enterprises are cited to be the environmental and climate-related aspects with the need for special education assessed as the least important, similar to the point of view of the experts surveyed. For GJ performance, students identified environmental and climate-related aspects as the most important, and economic aspects as the least important. Environmental and climate-related aspects were also valuated as the most important for the activities engaged in by the public, with the economic aspects being considered as the least important for this category.

In the joint assessment of experts and students, environmental and economic aspects are considered to be the most important in the performance of green companies, the need for special education is assessed the lowest in importance. In terms of the performance of GJs, environmental and climate-related aspects are valuated as the most important, and economic aspects as the least important. Environmental and climate-related aspects are assessed as the most important for activities engaged in by the public, and economic aspects - the least important.

Differences in the opinions of experts and students are observed in relation to GJs. However, in general, in all evaluated groups (green companies, GJs and public activities), the environmental aspect is indicated as the most important aspect for achieving results.

In the course of the work, a questionnaire was prepared on the role and contribution of local (Latvian) associations, foundations and non-governmental organizations in the development of the waste management system, including waste reduction and prevention and separate collection. Within the framework of the questionnaire, the above-mentioned environmental experts and students were invited to rank specific organizations (associations, foundations and non-governmental organizations) depending on their role and contribution to waste management, especially separate waste collection, both currently and in the future. They were also asked to provide justification of their valuation.

A broad range of associations, foundations and non-governmental organizations (NGOs) were chosen in terms of their form and objectives, but their unifying element was their scope, as they all work in the field of environmental protection, including waste management. Thus, the Latvian Environmental Science and Education Council, the Environmental Education Foundation are more involved in educational and research activities and their support. The association 'Zậa Brīvība' is a public environmental protection and environmental education organization, the mission of which is to promote the development of a society that lives in harmony with itself and the environment. It informs the public about the impact of consumer activity and globalization on nature and social environment, as well as the development, adoption and implementation of international legislation. The Environmental Advisory Council is a consultative co-ordinating institution, the purpose of which is to promote public participation in the development and implementation of environmental policy. The association 'Zero Waste Latvija' promotes a waste-free lifestyle and its members work in various fields - both in cooperation with the government, waste managers and producers in the development of various draft laws, and in the implementation of their own initiative projects. The association 'Pēdas' organizes an annual campaign for cleaning up the 
environment and collecting waste dumped in nature. Participants in the survey were also able to add other NGOs at their discretion.

The results obtained in the survey showed that both experts and students evaluate the activities engage in by the public depending on whether they have become acquainted with the activities of the particular NGO or have participated in the activities of these NGOs themselves. Therefore, the obtained results could not be used for further multi-criteria analysis. Therefore, general conclusions were drawn regarding the activities of certain types of environmental NGOs and the benefits to society. What can be unequivocally said is that the contribution of NGOs to the dissemination of environmental information and the formation of public opinion in the field of waste management is and will be greater, as the topic reaches the public in a more direct way. Consequently, NGOs can and must be involved in achieving waste reduction targets. However, the involvement of NGOs in public education requires a systemic and interdisciplinary approach. In addition, initiatives are relevant at various levels, both within enterprises, at the level of local authorities and municipalities, as well as at the regional, national and even international levels.

A multi-criteria analysis was used to assess the role and place of green enterprises, green jobs and activities engaged in by the general public in the development of the circular economy, including the waste management system. The multicriteria method chosen in this work is TOPSIS [24]-[26]. The main advantages of TOPSIS are the ability to choose an unlimited number of criteria and alternatives, a relatively simple calculation process, and TOPSIS results allow you to easily understand the alternatives. The choice of criteria is based on an approach that includes the widest possible range of aspects in the analysis. The criteria have been redesigned so that they can be compared with each other using specific indicators.

Using the TOPSIS analysis method, a decision matrix $D$ is created, which consists of criteria and alternatives, as shown in Eq. (1).

$$
D=A_{1}\left(\begin{array}{ccc}
C_{1} & \ldots & C_{n} \\
x_{11} & \ldots & x_{1 n} \\
\vdots & \ddots & \vdots \\
x_{m 1} & \ldots & x_{m n}
\end{array}\right),
$$

where

$$
\begin{aligned}
& A_{1} \ldots A_{m} \\
& C_{1} \ldots C_{n} \\
& X_{i j}
\end{aligned}
$$

Alternatives for comparison;

Criteria based upon which the comparison is made;

Alternatives $i$ (where $i$ is alternative 1 to $m$ ) value in accordance with criteria $j$ (where $j$ from 1 to $n$ ).

Each criterion is determined by its individual weight $w_{i}$. The weight is determined in such a way that the sum of the weight of all criteria is equal to 1 .

$$
\sum_{1=1}^{n} w_{i}=1
$$

After the decision matrix is developed, a normalization of the value is conducted and a matrix of the normalized decision-making is prepared by applying Eq. (3). 


$$
D_{\text {norm }}=A_{1}\left(\begin{array}{ccc}
C_{1} & \ldots & C_{n} \\
A_{m} & \ldots & r_{1 n} \\
\vdots & \ddots & \vdots \\
r_{m 1} & \ldots & r_{m n}
\end{array}\right),
$$

where $\mathrm{r}_{i j}$ is normalized value of alternative $i$ in accordance with criteria $j$.

The normalized value is calculated by using the Eq. (4):

$$
r_{i j}=\frac{x_{i j}}{\sqrt{\sum_{i=1}^{m} x_{i j}^{2}}} .
$$

In the next step, the normalized values are multiplied with the weight $w_{i}$ of the corresponding criteria $i$, thereby leading to the normalized weighted value $p_{i j}$, as shown in Eq. (5):

$$
p_{i j}=w_{i} \cdot r_{i j} .
$$

The normalized weighted decision matrix $D_{s v}$ provides the basis for the TOPSIS analysis.

$$
D_{s v}=\underset{A_{1}}{A_{m}}\left(\begin{array}{ccc}
C_{1} & \ldots & C_{n} \\
p_{11} & \ldots & p_{1 n} \\
\vdots & \ddots & \vdots \\
p_{m 1} & \cdots & p_{m n}
\end{array}\right)
$$

After the normalized weighted decision matrix is prepared, the ideal positive solution $\mathrm{A}^{+}$ and the ideal negative solution $\mathrm{A}^{-}$are calculated:

$$
\begin{aligned}
A^{+} & =\left(p_{1}^{+}, p_{2}^{+}, \ldots, p_{m}^{+}\right), \\
A^{-} & =\left(p_{1}^{-}, p_{2}^{-}, \ldots, p_{m}^{-}\right),
\end{aligned}
$$

where

$$
\begin{aligned}
& p_{j}^{+}=\left(\max _{i} p_{i j}, J \in J_{1} ; \min _{i} p_{i j}, J \in J_{2}\right), \\
& p_{j}^{-}=\left(\min _{i} p_{i j}, J \in J_{1} ; \max _{i} p_{i j}, J \in J_{2}\right) .
\end{aligned}
$$

Assuming that $J_{1}$ provides criteria, with maximum values for greater benefit and that $J_{2}$ indicates the criteria with higher values, the next step is to calculate the distance of each alternative from the positive ideal solution and negative ideal solution with Eq. (11) and Eq. (12).

The distance of the alternative from the positive ideal solution $\left(S^{+}\right)$is calculated:

$$
S^{+}=\sqrt{\sum_{j=1}^{n}\left(p_{i j}-p_{j}^{+}\right)^{2}}, i=1,2, \ldots, \mathrm{m} .
$$

The distance of the alternative from the negative ideal solution $\left(S^{-}\right)$is calculated: 


$$
S^{-}=\sqrt{\sum_{j=1}^{n}\left(p_{i j}-p_{j}^{-}\right)^{2}}, i=1,2, \ldots, \mathrm{m} .
$$

The alternative's relative distance from the ideal solution is calculated as shown with Eq. (13):

$$
C_{i}^{*}=\frac{S_{i}^{-}}{\left(S_{i}^{+}+S_{i}^{-}\right)}, i=1,2, \ldots, \mathrm{m} .
$$

As a result, the value obtained indicates the distance of the alternative to the ideal positive solution and to the ideal negative solution.

The results are shown in Fig. 2.

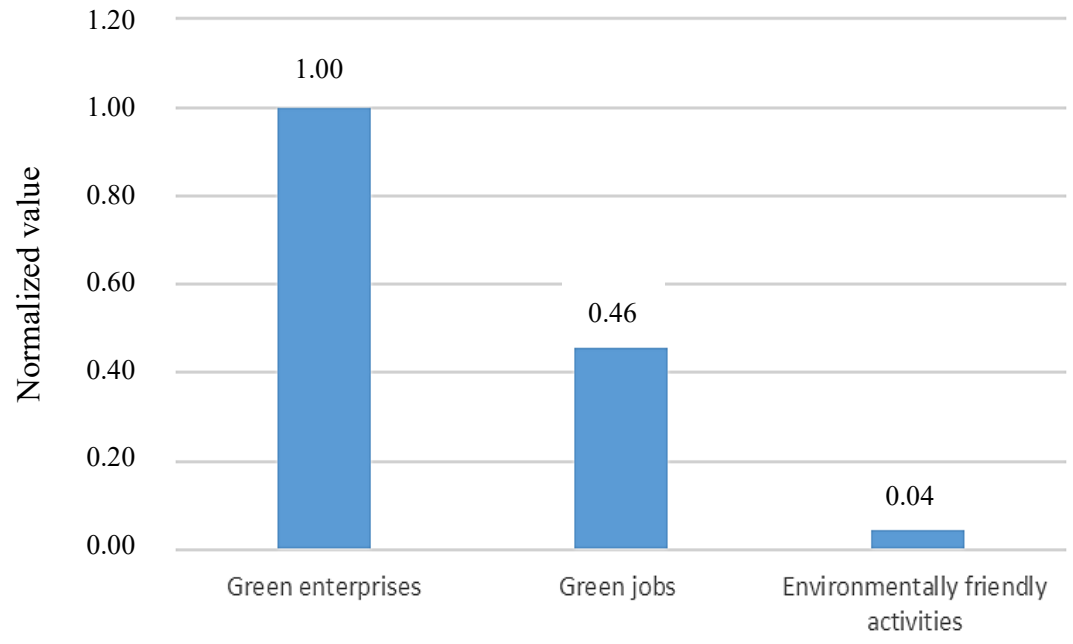

Fig. 2. Results of the ranking of green enterprises, green jobs and environmentally friendly activities engaged in by the public via the TOPSIS model.

In the course of the analysis, the results of the questionnaire, calculation of averages and application of the multi-criteria decision-making method (TOPSIS) clearly show that the most effective of the selected alternatives in the circular economy model within waste collection and recycling can be achieved through green enterprises.

\section{RESULTS AND DisCUSSION}

Based on the results of surveys and information analysis, the role of green enterprises, green jobs and environmentally friendly activities engaged in by society in the field of waste management were assessed, following the waste hierarchy in the circular economy model. According to the waste hierarchy [27], the priority is to prevent and reduce waste, followed by re-use, recycling and recovery.

The design of goods and packaging and the separate collection of waste are essential elements to ensure the highest possible rates of reuse, recycling and recovery. The design of goods and packaging is an essential element in preventing and reducing waste. 
The results obtained within the framework of the research indicate that the most important role in the circular economy model is played by green enterprises, i.e. enterprises, the main activity of which (according to the Statistical Classification of Economic Activities in the European Community (NACE)) is performed by providing environmental services. In the context of this work, these are companies that carry out waste management, from waste collection, including separate collection, transport, sorting, storage, preparation for re-use, treatment to waste recycling, recovery and disposal. Also included are companies that implement extended producer responsibility schemes and companies that act as consultants in the field of waste management. At the same time, it should be noted that not all jobs in these companies are considered GJs, because, like in any other company, there is a need for employees who perform support functions - provide administrative work and technical services.

\subsection{Green Enterprises}

In the circular economy model, there is an increasing need to reduce the amount of waste going to landfill, and this is associated with increasing resource efficiency. As a result, the role of waste recycling is growing, with a greater emphasis on recycling materials into other materials. This means developing waste recycling facilities to create new materials and new goods. With the development of recycling technologies, new companies are established, which are essential green companies, because they carry out waste recycling. The second direction in which green companies in the field of waste management are developing are companies that not only collect waste from their producers, but also collect waste separately, sort it and prepare it for recycling. Business has been developing especially in this direction in recent years. As the European Union has set a goal to dispose of no more than $10 \%$ of the amount of municipal waste generated in landfills per year in 2035, the changes also affect landfills, where waste management activities are developed and diversified - sorting and recycling facilities are created. Achieving the set goals requires companies that provide environmental consulting and public education and information, which can also be conducted by existing waste management companies, through the development of new competencies and skills in their current profile. Educating and informing the public is important in order that waste of the highest possible quality is sorted at the source, thus ensuring the preparation of better quality materials for recycling.

Another area which has developed significantly in recent years and is related to the reduction of waste and more efficient use of resources, is re-use - repair shops and companies that prepare things for re-use are increasing. This service presents an opportunity for expanding social entrepreneurship. These companies are also considered green companies.

With the development of waste management in line with the goals of the circular economy, the place and role of green companies in creating new jobs, a large part of which are GJs, is also significantly increasing. Consequently, the role of green companies is the most important in the development of the circular economy, as this is the fastest way to achieve waste management goals, while ensuring the creation of new jobs.

According to the results of the survey, the most important motivating aspects for the development of green enterprises are environmental protection requirements related to environmental impact assessment, pollution reduction and prevention options and economic aspects. In setting these requirements and the obligations of polluters, they must be reasonable, enforceable, clear and in line with the basic principles of environmental policy: the 'polluter pays' principle, the precautionary principle, prevention, the principle of evaluation and the principle of extended producer responsibility. In turn, the economic aspects that promote the development of green enterprises are related to the motivating tax 
policy set by the Government, the costs of the production of goods and provision of services and the motivating market demand policy for processed products. In turn, according to experts, the least important aspect in the development of green enterprises is specific education, which is related to the mobility of the population and readiness to acquire new skills and knowledge on the job.

The fact that green enterprises play a key role in waste management, as shown by the results of the survey and modelling carried out during the study, can be explained by the fact that these companies carry out specific planned waste management activities: waste collection, transport, sorting, recycling, recovery and recycling, disposal, preparation for re-use, repair and repair of cases to extend their service life. These activities are the core business of these companies. This includes companies involved in consultancy, the development and production of recycling technologies and techniques, and the development of products and packaging with the aim of reducing waste as such and reducing the amount of waste going to landfill. Respectively, the performance of these companies makes it possible to achieve these goals in the fastest way, in the most efficient way and with the highest numerical value.

\subsection{Green Jobs}

Green jobs (GJ) play an important role in the circular economy model in terms of waste management and resource efficiency, but their share is lower than that of green companies. Green jobs are jobs that help to preserve or restore the environment. It should be noted that GJs are located not only in green companies, but also in other companies and institutions, the core business of which is not related to the provision of environmental services, including waste management, but also to the development, assessment, enforcement, monitoring and control of environmental requirements and conditions or control (for example, environmental specialists/experts/consultants in companies and institutions, including control bodies). GJs are also associated with the development of new products and packaging, innovation and the efficient use of the company/institution resources, as a result of which the generation of waste is prevented and the amount of waste generated is reduced. Thus, GJs can be divided into several groups in relation to waste management policy in the circular economy model. The first is - jobs in green companies. The second - environmental specialists, the tasks of which are to ensure the development and maintenance of the company's/institution's environmental policy, including waste reduction and appropriate management, as well as place of employment related to goods and waste accounting, monitoring compliance with waste management requirements and control. GJs also include employees who innovate in the field of resource efficiency and through the development of new technologies and product prototypes, taking into account environmental and eco-design requirements and the principles of product life cycle analysis.

Evaluating the conducted research and expert evaluations, it can be concluded that the prestige of GJs is gradually increasing. This is related to the development of green products and services and the public's desire to live in an environment, the quality of which is high enough and does not deteriorate. The implementation of environmental management systems in companies also has a positive effect on the creation of GJs. According to the results of the survey, the most important motivating aspects for the development of GJs are the requirements of environmental protection and prevention of climate change. In turn, the least important are the economic aspects.

The results of the survey and modelling carried out during the study showed that the role of GJs is also important in achieving the goals of waste reduction and management. 


\subsection{Green Activities Engaged in by the Public}

By applying the Multi-Criteria Decision-Making Method (TOPSIS), the results clearly show that the selected alternative environmentally friendly activities engaged in by society have the lowest result in the model of circular economy in the field of waste management. However, these activities engaged in by the public cannot be underestimated, as they are related to the formation of public opinion and changes in behaviour. As in the case of GJs, environmental and climate-related aspects are the most important for the green activities which the public is engaged in, but economic aspects are the least important. It can be said that the activities of NGOs should be purposefully directed towards the transition of the society from waste management to waste reduction and prevention. It should also be noted that NGOs often focus on campaign-like activities that result in good publicity and positive public perceptions, but little work is done on effective long-term solutions.

\section{Conclusion}

1. Assessing the role of green enterprises, green jobs and environmentally friendly activities engaged in by society in the field of waste management, following the waste hierarchy in the circular economy model, the results clearly show that the most effective of the selected alternatives can be achieved through the activities of green enterprises, then green jobs the least effective being the activities engaged in by the public.

2. Whereas the collection, transport, sorting, treatment, recycling, recovery and disposal of waste, preparation for re-use, repair of items and repairs, consultancy, development and production of recycling technologies and techniques and the development of products and packaging with a view to reducing waste and landfilling is the core business of green companies, the performance of these companies makes it possible to achieve waste management goals in the most efficient way and with the highest numerical value.

3. The most important motivating tools for the development of green enterprises are environmental protection requirements related to environmental impact assessment, pollution reduction and prevention options, and economic aspects. The economic aspects that promote the development of green enterprises are related to the motivating tax policy set by the Government, the costs of production of goods and provision of services and the motivating market demand policy for processed products.

4. The tools which motivate green job creation and development in the field of waste management are the development of green products and services, the public's desire to live in a quality environment and the implementation of environmental management systems in companies.

5. The most important motivating aspects in the development of green jobs and environmentally friendly activities engaged in by society are the environmental and climate-related aspects, but the least important are the economic aspects.

6. The activities of NGOs should be purposefully directed towards activities which promote the transition of the activities engaged in by the public from waste management to waste reduction and prevention.

7. To evaluate the efficiency of green enterprises, green jobs and environmentally friendly activities engaged in by society in the field of waste management, activity indicators are related to the waste hierarchy within the circular economy model - the amount of waste generated decreases, the amount of waste disposed of decreases, the amount of recyclable and recycled waste increases. However, different indicators apply to each group, as green businesses are designed to manage waste efficiently. In turn, the role and significance of 
green jobs and the activities of the public is related not only to proper waste management, but also to the reduction of waste and prevention of its generation.

\section{REFERENCES}

[1] European Commission. Communication From The Commission To The European Parliament, The Council, The European Economic And Social Committee And The Committee Of The Regions. A new Circular Economy Action Plan. For a cleaner and more competitive Europe. Brussels: EC, 2020.

[2] International Labour Organization. Guidelines for a just transition towards environmentally sustainable economies and societies for all. Geneva: ILO, 2015.

[3] Communication From The Commission To The European Parliament, The Council, The European Economic And Social Committee And The Committee Of The Regions. Green Employment Initiative: Tapping into the job creation potential of the green economy. Brussels: EC, 201.

[4] International Labour Organization. Green jobs progress report 2014-2015. Geneva: ILO, 2016.

[5] International Labour Organization. Decent work. Geneva: ILO, 2018.

[6] International Labour Organization. Greening with jobs. World Employment Social Outlook 2018. Geneva: ILO, 2018.

[7] Jacob K., Quitzow R., Bär H. Green Jobs: Impacts of a Green Economy on Employment. Eschborn: GIZ, 2015.

[8] Novello A., Carlock G. Redefining green Jobs for a Sustainable Economy. Report Economy \& Jobs. 2019.

[9] Khoshnava S. M., et al. Green efforts to link the economy and infrastructure strategies in the context of sustainable development. Energy 2020:193:116759. https://doi.org/10.1016/i.energy.2019.116759

[10] Bowen A., et al. Characterising green employment: The impacts of 'greening' on workforce composition. Energy 2018:72:263-275. https://doi.org/10.1016/j.eneco.2018.03.015

[11] International Labour Organization. What is a green job? [Online]. Available: https:/www.ilo.org/global/topics/greenjobs/news/WCMS_220248/lang--en/index.htm

[12] Sulich A., Rutkowska M., Popławski L. Green jobs, definitional issues, and the employment of young people: An analysis of three European Union countries. Journal of Environmental Management 2020:262:110314. https://doi.org/10.1016/j.jenvman.2020.110314

[13] Battaglia M., Cerrini E., Annesi N. Can environmental agreements represent an opportunity for green jobs? Evidence from two Italian experiences. Journal of Cleaner Production 2018:175:257-266. https://doi.org/10.1016/j.jclepro.2017.12.086

[14] Dell'Anna F. Green jobs and energy efficiency as strategies for economic growth and the reduction of environmental impacts. Energy Policy 2021:149:112031. https://doi.org/10.1016/j.enpol.2020.112031

[15] Cecere G., Mazzanti M. Green jobs and eco-innovations in European SMEs. Resource and Energy Economics 2017:49:86-98. https://doi.org/10.1016/j.reseneeco.2017.03.003

[16] Martínez-Cruz A. L., Núñez H. M. Tension in Mexico's energy transition: Are urban residential consumers in Aguascalientes willing to pay for renewable energy and green jobs? Energy Policy 2021:150:112145. https://doi.org/10.1016/j.enpol.2021.112145

[17] Consoli D., et al. Do green jobs differ from non-green jobs in terms of skills and human capital? Research Policy 2016:45(5):1046-1060. https://doi.org/10.1016/j.respol.2016.02.007

[18] Lorraine E., et al. Waste Reduction Behaviors at Home, at Work, and on Holiday: What Influences Behavioral Consistency Across Contexts? Front. Psychol. 2018:9:2447. https://doi.org/10.3389/fpsyg.2018.02447

[19] Breakwell G. M. Identity process theory: clarifications and elaborations. Identity Process Theory: Identity, Social Action and Social Change. Cambridge: Cambridge University Press, 2014:203-221.

[20] Young W., et al. Changing behaviour: successful environmental programmes in the workplace. Business Strategy and Environment 2015:24(8):689-703. https://doi.org/10.1002/bse.1836

[21] Fuldauer L. I., et al. Participatory planning of the future of waste management in small island developing states to deliver on the Sustainable Development Goals. Journal of Cleaner Production 2019:223:147-162. https://doi.org/10.1016/j.jclepro.2019.02.269

[22] Inghels D., Dullaert W., Bloemhof J. A model for improving sustainable green waste recovery. Resources, Conservation and Recycling 2016:110:61-73. https://doi.org/10.1016/j.resconrec.2016.03.013

[23] Lanfranchi J., Pekovic S. How Green is my Firm? Workers' Attitudes and Behaviors towards Job in Environmentally Related Firms. Ecological Economics 2014:100:16-29. https://doi.org/10.1016/j.ecolecon.2013.12.019

[24] Hwang C. L., Yoon K. (1981) Multiple Attribute Decision Making: Methods and Applications A State-of-the-Art Survey. New York: Springer-Verlag, 1984. http://dx.doi.org/10.1007/978-3-642-48318-9

[25] Hrasko R., Pacheco A. G. C., Krohling R. A. Time Series Prediction Using Restricted Boltzmann Machines and Backpropagation. Procedia Computer Science 2015:55:990-999. https://doi.org/10.1016/j.procs.2015.07.104

[26] Krohling R. A. Pacheco A. G. C. A-TOPSIS - An approach Based on TOPSIS for Ranking Evolutionary Algorithms. Procedia Computer Sciences 2015:55:308-317. https://doi.org/10.1016/j.procs.2015.07.054

[27] European Commission. Waste prevention and management [Online]. [Accessed 15.03.2021]. Available: https://ec.europa.eu/environment/green-growth/waste-prevention-and-management/index_en.htm 